

ARAȘTIRMA MAKALESI

\title{
Hasta Hekim İletişimi ile Hekimin Tekrar Tercih Edilmesi İlişkisi: Bir Kamu Hastanesi Örneği
}

Uzm. Hemş. Burcu KAYA, İlkadım İlçe Sağlık Müdürlüğü, Samsun, e-posta: seymanburcu@windowslive.com

ORCID: https://orcid.org/0000-0003-0657-6513

Dr. Öğr. Üyesi Rukiye ÇELIKK, Süleyman Demirel Üniversitesi, Isparta, e-posta: bursa84@hotmail.com

ORCID: https://orcid.org/0000-0002-2538-0228

Doç. Dr. Ömer Lütfi ANTALYALI, Süleyman Demirel Üniversitesi, Isparta, e-posta: omerantalyali@sdu.edu.tr

ORCID: https://orcid.org/0000-0002-9600-9581

Öz

$\mathrm{Bu}$ çalışmasının amacı, hasta hekim iletişimi ile hekimin tekrar tercih edilme durumunun arasındaki ilişkiyi araştırmaktır. Evreni bir kamu hastanesi olan çalı̧̧mada örneklem, kolayda örnekleme yöntemi ile belirlenmiştir. İki ayrı klinikten ikişer hekimin hastalarından veri toplanmıştır. Her bir hekimin ortalama 100 hastası ile görüşülerek toplamda 401 hastaya ulaşılmıştır. Çalışmada hasta hekim iletişimini ölçen iki ölçekten esinlenerek oluşturulan "Hasta Hekim İletişim Anketi" isimli bir veri toplama aracı kullanılmıştır. Araştırma sonuçları; hasta hekim iletişimi ile hekim tercihinin arasında olumlu ilişki olduğunu göstermiştir. Hastaların $\% 92$ 'sinin, hekimlerinin iletişimlerini iyi olarak değerlendirdiği, hekimlerinin iletişimlerini iyi olarak değerlendiren hastaların \%95'inin de aynı hekimi tekrar tercih edeceği tespit edilmiştir. Tüm hastaların \%90'ının aynı hekimi tekrar tercih edeceği, \%54'ünün başka hekime muayene olmak istemediği, aynı hekime devam edeceği ve \%79'unun hekimini başkalarına tavsiye edeceği tespit edilmiştir. Ayrıca hastanın cinsiyet, medeni durum, yaş ve eğitim gibi bazı demografik özelliklerinin, hasta hekim iletişiminde etkili olduğu görülmüsştür. Dolayısıyla hastanın aynı hekimi tercih etmesi için hekimin hastaya daha açıklayıcı bir tedavi süreci oluşturması, psikolojik destek sağlaması ve yapılan tetkiklerin sonuçlarını anlatması önerilmektedir.

Anahtar Kelimeler: Hasta Hekim İletişimi, Hekim Tercihi, Sağlık İletişimi.

Makale Gönderme Tarihi: 24.07.2019

Makale Kabul Tarihi: 03.11.2019

\section{Önerilen Atıf:}

Kaya, B., Çelik, R. ve Antalyalı, Ö. L. (2019). Hasta Hekim İletişimi ile Hekimin Tekrar Tercih Edilmesi İlişkisi: Bir Kamu Hastanesi Örneği, Sosyal, Beşeri ve İdari Bilimler Dergisi, 2(11): 801-814. (C) 2019 Sosyal, Beşerî ve İdari Bilimler Dergisi. 


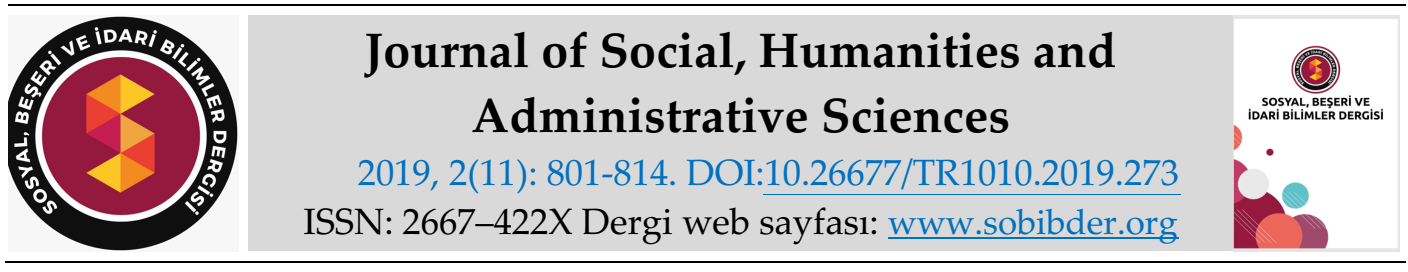

RESEARCH PAPER

\title{
Relationship between Patient Physician Communication and Physician Re- Preference: The Case of Public Hospital
}

\author{
Burcu KAYA MSc, Ilkadım District Health Directorate, Samsun, e-mail: \\ seymanburcu@windowslive.com \\ ORCID: https://orcid.org/0000-0003-0657-6513
}

Assistant Prof. Dr. Rukiye ÇELIK, Süleyman Demirel University, Isparta, e-mail: bursa84@hotmail.com

ORCID: https://orcid.org/0000-0002-2538-0228

Associate Prof. Dr. Ömer Lütfi ANTALYALI, Süleyman Demirel University, Isparta, email:omerantalyali@sdu.edu.tr

ORCID: https://orcid.org/0000-0002-9600-9581

\begin{abstract}
The aim of this study is to investigate the relationship between patient physician communication and physician re-preference. In the study of the universe as a public hospital, the sample is easily determined by the sampling method. Data from the patients of two physicians were collected from 2 separate clinics. A total of 401 patients were reached with the average 100 patients of each physician. In the study, a data collection tool called "Patient Physician Communication Questionnaire" was used, which was inspired by two measures measuring patient physician communication. The results of the study showed that there was a positive relationship between patient physician communication and physician preference. It was determined that $92 \%$ of the patients evaluated the communication of their physicians and $95 \%$ of the patients who evaluated the communication of their physicians as well would prefer the same physician again. $90 \%$ of all patients will prefer the same physician again, $54 \%$ do not want to be examined by another doctor, and the same doctor will continue to recommend $79 \%$ of physicians to others have been determined. In addition, some demographic characteristics of the patient, such as gender, marital status, age and education, were found to be effective in-patient physician communication. Therefore, for the patient to choose the same physician, it is recommended that the physician create a more descriptive treatment process for the patient, provide psychological support and explain the results of the examinations performed.
\end{abstract}

Keywords: Patient Physician Communication, Physician Preference, Health Communication.

Received: 24.07.2019

Accepted: 03.11.2019

Suggested Citation:

Kaya, B., Çelik, R. and Antalyalı, Ö. L. (2019). Relationship between Patient Physician Communication and Physician Re-Preference: The Case of Public Hospital, Journal of Social, Humanities and Administrative Sciences, 2(11): 801-814.

(C) 2019 Sosyal, Beşerî ve İdari Bilimler Dergisi. 


\section{Gíriş}

Sağlık iletişimi kapsamında; sağlık çalışanlarının kendi aralarında iletişimi, sağlık hizmeti sunan personel ile hasta ve hasta yakınlarının iletişimi gibi çeşitli konular yer almaktadır. Sağlık kurumlarında sağlık hizmeti almaya gelen hastalarla hekimler arasında kurulacak iletişim için hekimlerin davranışları önemlidir. Sağlık iletişimi, sağlık ile alakalı konuların ilgili kişi veya gruplar tarafından farklı değişkenliklere sahip kişilere ve gruplara ulaştırılmasıdır (Okay, 2009: 21).

Bir hastanın eğitim durumu, ekonomik seviyesi, sosyo-demografik özellikleri, sosyal statüsü, anlama kapasitesi gibi birçok faktör, hastanın hekimden gelen mesajı doğru anlama ve yorumlamadaki başarısını etkileyebilmektedir (Street, 2003: 69). Hasta hekim ilişkisi, hizmet veren hekimler ve hizmet alan hastalar açısından önem taşımaktadır. Hekimi ile olumlu ilişki kuran hastanın aynı hekimi tekrar tercih etme olasılığı artmaktadır. Etkili bir hasta hekim iletişiminin; hastanın hekiminden memnun kalması ve aynı hekimi tekrar tercih etmesi gibi bazı somut yararları da vardır (Gordon ve Edwards, 1997: 19). Hekimlerinin tıbbi yetenekleri, yeterlilikleri, bilgi ve becerileri kadar hekimlerin sevecen, dostça yaklaşımları, açıklayıcı tutumları ve hastasını tedaviye katılımı için desteklemeleri de hastaların memnuniyetlerini artırmaktadır (Şahin, 1999: 71). İyi bir iletişim süreci yürütemeyen bir hekim diğer tüm yeterlilikleri ne seviyede olursa olsun tam anlamıyla başarıya ulaşamamaktadır (Kurtz vd., 1998: 16). Hastanın hekim seçmesinde ve değiştirmesinde etkili olan hekimin tıbbi yeterliliğinin yanında hekimin iletişim becerilerinin de payının büyük olduğu görülmektedir. Bu çalışmada hasta hekim arasındaki iletişimin hekimin tekrar tercih edilme durumu ile arasındaki ilişki araştırılmıştır.

\section{SAĞLIK İLETIŞIMI}

İletişim hayatın doğasında var olan, örgütsel yapıları oluşturmaya yarayan, kişilerin, toplulukların, örgütlerin birbirleri ile olan ilişkilerini kurmayı sağlayan bir araçtır (Sabuncuoğlu ve Tüz, 1998: 107). Sağlık, birçok boyutuyla öncelikle toplumsal bir olgudur (Cirhinlioğlu, 2001b: 5).

Sağlıkta ve hastalıkta iletişim; insanın yaşadığı deneyimlerin en önemli boyutudur. Hiçbir insani olgu hastalık ve sağlık kadar temel nitelikte değildir. Ayrıca hiçbir olgu insanın iç dünyasındaki istek ve arzularını bu kadar etkilememiştir (Bulduklu ve Koçak, 2010: 63). Sağlık iletişiminin; yaşam kalitesinin artırılması, sağlıklı bir insan olabilme ve hastalıkların önlenmesi açısından önemli bir rolü bulunmaktadır (Rimal ve Lapinsk (2009: 247). İnsan iletişiminin, iletişim dalının bir alt sistemi olduğu, sağllk iletişiminin ise insan iletişiminin alt sistemi olduğu kabul edilmektedir (Tabak, 2006: 29).

Sağlık iletişimi; medya, sosyal pazarlama ve halkla ilişkiler yöntemlerini kullanarak sağlığın geliştirilmesi ile ilgili alanlarda önemli ölçüde katkılar sağlamaktadır. Sosyal pazarlamada, sigara tüketiminin azaltılması, kanser veya AIDS gibi hastalıklarla mücadele etme ve trafik kazalarının azaltılması konularında pazarlama teknikleri kullanılarak sağlık iletişimi kampanyaları hazırlanmaktadır (Çınarlı, 2008: 45). Sağlık iletişimi alanında hazırlanan kamu spotları medya savunuculuğunun adımlarından biridir (Sezgin, 2008: 157).

İletişimin sağlık konusunda ilgili birey veya gruplar ile yapılmasına sağlık iletişimi denmektedir (Okay, 2009: 21). Sağlık kurum ve kuruluşlarında sağlık çalışanları arasında kurumsal kültür çerçevesinde ve kurumsal bir hava içerisinde gerçekleşen iletişim için sağlık iletişimi terimi kullanılmaktadır (Tabak, 1999: 30). Bahsedildiği gibi sağlık iletişimi sağlık çalışanları, hasta-hasta yakınları ve hastane başta olmak üzere birçok kurum ve kuruluşları ilgilendiren bir alandır. 
Sağlık iletişiminin sağlığın korunması görevinin yanı sıra HIV, verem, diyabet, tansiyon, obezite gibi önemli hastalıklar hakkında kamuoyunu bilinçlendirmek gibi birçok görevi vardır.

Sağlıklı bir toplumun meydana gelmesi ve toplumun mevcut sağlıklı durumunu devam ettirebilmesi için hasta ile hekim arasında ilişkilerin niteliği çok önemlidir. Hekimin başarısından bahsetmek için hastanelerdeki tanı koyma ve tedavi etme sırasında hekimin hastalarla kurduğu ilişkilerdeki iletişim becerisinin önemi büyüktür (Cirhinlioğlu, 2001a: 59).

\section{Hasta Hekim İletişimi}

"Hasta hekim ilişkisi" tıpta değişmeyen bir olgu olarak tanımlanmakta ve tıbbın değişmeyen amacı olarak korunmaktadır (Chin, 2001: 579). Hasta hekim ilişkisinde hasta ile hekim arasında geçen iletişim kişilerarası iletişim kapsamına girmektedir. Kişiler arası iletişim; problem çözme, rahatlatma, bilgi verme, ikna etme, duyguları açığa çıkarma ve karar verme gibi birçok amaca hizmet etmektedir (Atıc1, 2007: 92). Hekimlik gibi hizmet üreten mesleklerde iletişim becerileri hizmetin kalitesini etkileyen unsurlardan biridir. Hasta hekim iletişimi, hasta ve hekimin, tedaviye yönelik birlikte başarmaya çalıştıkları hedefleri gerçekleştirme yolunda temel bir unsurdur (Kostik, 1999: 72).

Hasta hekim arasındaki iletişimin gücü ve iletişimin biçimi tıbbi tedavinin başarısını etkilemektedir. Hekimler tıbbi başarılarının yanında hastaların beklenti ve ihtiyaçlarını fark etmeli ve bu beklentilere karşılık vermelidir (Hardoff vd., 2001: 209). Bu bakış açısıyla hastaların hekimlerden bekledikleri, hasta gereksinimlerini karşılamaları, hastaların korku ve streslerini en aza indirgemeleridir.

Hekimlerin hastalara koydukları tanıların \%70'inin başarılı bir hasta hekim iletişiminden sonra ortaya çıktığı tespit edilmiştir (Akkoç ve Güldal, 2001: 77). Başarılı bir hasta hekim iletişiminin hem hekime hem de hastaya katkısı büyüktür. Başarılı hasta hekim iletişimi her iki taraf için de yararlı olmaktadır (Gordon ve Edvard, 1997: 19).

\section{Hasta Hekim İletişiminin Hekim Tercihine Etkisi}

Kaliteli hasta hekim iletişimi hasta tatminini sağlamakla beraber alınan hizmetin kalitesinin de artmasını sağlamaktadır. Hastaların aynı sağlık kurumunu ve aynı hekimi tekrar tercih etmelerinde hastanenin fiziki koşularından ve tıbbi olanaklardan daha çok hekimin tutum ve davranışlarından doğan hasta memnuniyeti daha çok etkili olmaktadır. Hasta ile hekim arasındaki iletişimin hasta memnuniyetinde önemli bir yeri vardır (Kavuncubaşı, 2000: 291). Hekim ile hasta arasında gerçekleşen etkili iletişimin somut faydaları bulunmaktadır. Somut fayda olarak hastaların daha erken taburcu olduğu, hekimlere yanlış tedavi nedeni ile açlan davaların azaldığı, hekimlerini dinleyen, onun tavsiyelerine uyan hastaların sayısının yükseldiği, hastaların hekimlerinden memnun kaldığı ve hekiminden memnun kalan hastaların daha az hekim değiştirdiği, ihtiyaç halinde aynı hekimi tekrar tercih ettiği gözlenmektedir (Gordon ve Edwards, 1997: 19).

Hasta hekimini seçerken en iyi hekim olmasını amaçlamaktadır ve iyi hekim terimi yukarıda belirtilen özelliklere göre hekimden hekime değişmekte ve hastanın bakış açısı ile farklılık göstermektedir. Bir hekimin mesleki beceri ve başarıları hasta memnuniyeti için yeterli olamamaktadır. Ancak hekim, mesleki başarıyı iletişimsel başarı ile birleştirip harmanlarsa tam anlamıyla başarı elde etmiş olacaktır (Özlü, 2003: 52). İyi bir iletişim süreci yürütemeyen bir hekimin diğer tüm yeterlilikleri ne seviyede olursa olsun tam anlamıyla başarıya ulaşamamaktır (Kurtz vd., 1998: 16). 
İnsanlar genelde kendilerini seven insanları sevme eğilimindedirler ve araştırmacı, insanlar eğer sevilmediğini hissederler ise bu duygunun da karşılıklı olacağını belirtmektedir. Kişi güvendiği insanların uyarı ve tavsiyelerine daha çok uyma eğilimi göstermektedir ve hastalar da daha çok güvendikleri hekimlerin önerilerini dikkate alıp uygulamakta, güvendikleri ve iyi bir iletişim kurdukları hekimleri tercih etmektedir (Freedman, 1998: 201).

\section{ARAŞTIRMANIN YÖNTEMI}

Özel hastanelerin çoğalması ve teknolojinin ilerlemesi ile insanların hastaneleri, hekimleri ve tedavi yöntemlerini tercih etme olanağı artmıştır. Hastanelerde hekimin, hastasıyla iletişim kurarak, hastalarını bilgilendirmesinin zorunlu olduğu bir yapılanmaya doğru gidilmeye başlanılmıştır. Hastaları memnun edip aynı hastaneye tekrar gelmelerini isteyen kurumlar ve hekimler hastaları artık müşteri olarak görmektedir. Bunun yanı sıra, sağlıklı bir toplumun meydana gelmesi ve toplumun mevcut sağlıklı durumunu devam ettirebilmesi için hasta ile hekim arasında ilişkilerin niteliği çok önemlidir. (Cirhinlioğlu, 2001a: 59). Türkiye'deki sağlık kurumlarında, hasta ile hekim arasında geçen problemlerden en önemlisi iletişim sırasında oluşan problemlerdir. Hasta ile hekim arasındaki iletişim, hasta memnuniyeti, hasta tatmini ve hasta hakları açısından oldukça önemli bir konu olarak karşımıza çıkmaktadır.

Hasta hekim iletişimi, hem hasta hem de hekimin karşılıklı etkilendiği bir süreçtir ki bu süreç hastanın problemlerini tanımlama ve çözme konusunda oldukça önemli bir yere sahiptir. Bu çalışma, hekim iletişimi ile hekimin tekrar tercih edilme durumunun arasında bir ilişki olup olmadığı konusunda bazı sonuçlar verecektir.

Hekim iletişimi ile hekimin tekrar tercih edilme durumunun arasındaki ilişkiyi incelemek bu çalışmanın temel amacıdır. Başka bir ifadeyle bu çalışmada; "hekimin iletişimini iyi olarak değerlendiren hasta, ayn hekimi tekrar tercih edecek mi?" sorusuna cevap aranmaktadır. Ayrıca bu çalışma, hekim iletişimi ile hekim tercihi arasındaki ilişkiyi ve hasta hekim iletişimi ile hastanın sahip olduğu sosyo-demografik özellikler arasındaki ilişkiyi bir ölçek yardımı ile değerlendirip, sonuçları verilere dayandırarak sunmayı planlamaktadır.

$\mathrm{Bu}$ amaçlar çerçevesinde aşağıdaki sorulara cevap aranacaktır.

- Hasta ile hekim arasındaki iletişimin, hekimin tekrar tercih edilmesi ile bir ilişkisi var midir?

- Hasta-hekim iletişimindeki hekimin açıklayıcı tavrının, hekimin tekrar tercih edilmesi ile bir ilişkisi var mıdır?

- Hasta-hekim iletişimindeki hekimin hastaya verdiği psikolojik desteğin, hekimin tekrar tercih edilmesi ile bir ilişkisi var mıdır?

- Hasta-hekim iletişimindeki hekimin hastaya yaptığı tetkiklerin, hekimin tekrar tercih edilmesi ile bir ilişkisi var mıdır?

Bu çalışmada hasta hekim iletişimi ile hekimin tekrar tercihi arasındaki ilişkiyi belirlemek amacı ile korelasyon (ilişkisel) tarama deseninden faydalanılmıştır. Karasar'a (2014: 81) göre korelasyon taramada iki veya daha fazla değişken arasında, beraber değişmenin derecesi ve varlığı betimlenmek amaçlanmıştır. Araştırmada nicelik tarama modelleri ile bir kamu hastanesine sağlık hizmeti almak için başvuran hastaların kişisel özellikleri ve hasta hekim iletişimi ile ilgili görüşleri yüz yüze yapılan anket tekniği ile betimlenmiştir. Avrupa ülkelerinde kullanılan ve hasta hekim iletişimini ölçen çalışmaların ana kaynağı olan Valori vd., (1996) tarafından geliştirilen PRF (The Patient Requests Form) anketinden ve bu anketin kisa formu olan Van Den Brink-Muinen vd., (2000)'in PRF-Short Form anketinden esinlenilerek yeni bir anket oluşturulmuştur. 
Araştırmanın evrenini, bir kamu hastanesinde sağlık hizmeti almak için başvuran hastalar oluşturmaktadır. Araştırmanın örneklem grubunu ise bir kamu hastanesinin bünyesinde bulunan kolayda örnekleme yöntemi ile seçilen Göz ile Fizik Tedavi ve Rehabilitasyon polikliniklerinde muayene olan hastalar oluşturmaktadır. Her bir poliklinikte iki hekim hizmet vermektedir. Uygulamanın yapıldığı hastaneden alınan istatistiklere göre söz konusu hekimlere haftalık ortalama 250 'şer hasta başvurmaktadır. Bu sayı poliklinik olarak değerlendirildiğinde 500 olmaktadır. Örneklem grubu, hesaplama programlarına göre; yüksek güvenirlik seviyesi $(0,05)$ ve düşük hata oranı $(0,04)$ elde edebilmek için, 1000 hastadan en az 375'ine ulaşmak gerekmektedir. Çalışmada 25 Haziran-1 Temmuz 2014 tarihleri arasında toplam 401 hastaya anket uygulanmıştır. Bu rakam; kümeleme yolu ile her bir hekimin eşit sayıda hastasına anket uygulanması ile elde edilmiştir. Sonuç olarak çalışmanın istatiksel olarak yüksek bir geçerlilik ve güvenirlik oranına ulaşılmış olması bilimsel açıdan oldukça önemlidir.

$\mathrm{Bu}$ araştırma; Isparta ilinde bulunan bir kamu hastanesinde, Göz polikliniği ile Fizik tedavi ve Rehabilitasyon polikliniğine sağlık hizmeti almak için başvuran hastaların görüşleri ile sınırlı kalmıştır. Ayrıca araştırma Isparta ilinde bulunan bir kamu hastanesini kapsadığı için sonuçlar bu evrenin özelliklerini yansıtmaktadır. Bu nedenle çalışmanın herhangi bir genelleme yapma iddiası bulunmamaktadır. Araştırmanın tüm hastalara genellenebilmesi için daha geniş çaplı örneklem üzerinde çalışılması gerekmektedir.

Araştırmanın, konu ile ilgili yapılan diğer çalışmalardan farklı bir niteliğe ve kendine özgün bir değere sahip olmasından dolayı var olan akademik boşluğa katkı sağlaması beklenmektedir. Ayrıca bu araştırmanın gelecekte bu konu ile ilgili yapılacak olan çalışmalara kaynak olarak yarar sağlayacağı düşünülmektedir.

\section{BULGULAR}

Yapılan uygulama sonucunda elde edilen veriler, hasta hekim iletişim anketinin yapı geçerliğini incelemek için doğrulayıcı faktör analizine tabi tutulmuştur. Hasta hekim iletişimini değerlendiren 41 soru faktör analizi bulguları ve kapsam geçerliliğine dikkat edilerek 16 soruya indirilmiştir. Birbirine benzeyen sorular arasında faktör yapısına en uygun olanlar tercih edilmiştir. 16 soru ile \%61 açıklayıcılıkta 3 faktörlü yapı elde edilmiştir. Elde edilen 3 faktörlü yapı gerek Valori vd. (1996)'nın gerekse de Van Den Brink-Muinen vd. (2000)'in elde ettiği faktör yapısı ile uyumludur. Sadece 1 soruda Valori vd. (1996) ile farklılık söz konusudur. "Tetkik" ile ilgili olan bir soru Valori ölçeğinde "Açıklama" boyutunda ele alınmıştır. Bu soru Van Den BrinkMuinen ölçeğinde ise mevcut değildir. Bu çalışmada bahsi geçen soru "Tetkik" boyutuna yüklenmiştir. Daha doğru bir yapı olduğu düşüncesi ile sorunun çıkarılması yerine "Tetkik" boyutunda kullanılması uygun görülmüştür.

Sonuç olarak hasta-hekim iletişimini ölçmek için yapılan faktör analizi sonucuna göre bu araştırmanın veri toplama kısmında açıklama, psikolojik destek ve tetkik boyutları olmak üzere 3 boyutlu nitelikli bir ölçek kullanılmıştır.

Birinci faktörde 9 değişken bulunmaktadır. Değişkenlerin ortalamaları 4 üzerinden 1,89-2,45 arasındadır. Dönüştürülmüş bileşen matris katsayıları 0,78-0,87 arasındadır. Oransal ortak evren varyansları 0,46-0,62 arasındadır. Madde toplam korelasyonları 0,58-0,69 arasındadır. 9 soruluk ölçeğin güvenilirlik alpha değeri ise $0,88^{\prime}$ dir. Bu faktörde bir araya gelen soru grubu "Açıklama Boyutu" olarak isimlendirilmiştir.

İkinci faktörde 4 değişken mevcuttur. Değişkenlerin ortalamaları 4 üzerinden 1,44-1,65 arasındadır. Dönüştürülmüş bileşen matris katsayıları 0,63-0,73 arasındadır. Oransal ortak evren varyansları 0,68-0,76 arasındadır. Madde toplam korelasyonları 0,65-0,75 arasındadır. 4 soruluk 
ölçeğin güvenilirlik alpha değeri ise 0,84 'tir. Bu faktörde bir araya gelen soru grubu "Psikolojik Destek Boyutu" olarak isimlendirilmiştir.

Üçüncü faktöre ise 3 değişken yüklenmiştir. Değişkenlerin ortalamalar1 4 üzerinden 2,58-2,93 arasındadır. Dönüştürülmüş bileşen matris katsayıları 0,70-0,86 arasındadır. Oransal ortak evren varyansları 0,59-0,75 arasındadır. Madde toplam korelasyonları 0,50-0,73 arasındadır. 3 soruluk ölçeğin güvenilirlik alpha değeri ise 0,80 'dir. Bu faktörde bir araya gelen soru grubu ise “Tetkik Boyutu" olarak isimlendirilmiştir.

Hasta-hekim iletişimini ölçmek için yapılan faktör analizi sonucuna göre açıklama, psikolojik destek ve tetkik boyutları olmak üzere 3 boyutlu nitelikli bir ölçeğe ulaşıldığı söylenebilir. PRF (ThePatientRequests Form) anketinden esinlenerek Türkçeye "Hasta Hekim İletişim Anketi" şeklinde uyarlanmış olan bu anket, hasta ile hekim arasındaki iletişimi ölçen 3 boyutlu güvenilir ve geçerli bir ölçme aracıdır.

\section{Hasta Hekim İletişimine İlişkin Bulgular}

Araştırmaya katılan hastaların "hasta hekim iletişimi" ile ilgili tanımlayıcı ifadelere verdikleri cevapların aritmetik ortalaması ve standart sapması Tablo 1'de gösterilmektedir.

Tablo 1'de görüldüğü üzere soru 1'de "Hekim hastalığınızın belirtilerini size söyledi mi?" sorusuna hastaların çoğu $(2,12)$ olumlu cevap vermiştir. Soru 2'de "Hekim muayene sırasında hastalığınızın nedenini size anlattı mı?" sorusuna hastaların çoğu $(2,16)$ anlattı cevabını vermiştir. Soru 3'te "Hekim hastalığınızın gidişatını size açıladı mı?" sorusuna hastaların çoğu $(2,18)$ olumlu cevap vermiştir. Soru 4'te "Hekim hastalığınızın ciddiyetini size açıkladı mı?" sorusuna hastaların çoğu $(2,15)$ açıkladı cevabını vermiştir. Soru 5'de "Hekim hastalığınızın ciddiyetini size açıkladı mı?" sorusuna hastaların çoğu $(2,40)$ açıkladı cevabını vermiştir. Soru 7 ' de "Hekim tıbbi tedaviniz ile ilgili size tavsiyelerde bulundu mu?" sorusuna hastaların çoğu $(2,27)$ olumlu cevap vermiştir. Soru 8'de "Hekim hastalığınız ile ilgili sizin düşündüklerinizi anladı mı?" sorusuna hastaların çoğu $(2,45)$ olumlu cevap vermiştir. Soru 9'da "Hekim hastalığınızla ilgili hissettiklerinizi anladı mı?" hastaların çoğu $(2,33)$ olumlu cevap vermiştir. Soru 14'de "Hekim hastalığınızın nedenini bulmak için testler yaptı mı?" sorusuna hastaların çoğu $(2,93)$ olumlu cevap vermiştir. Soru 15' de "Hekim bazı test sonuçlarını size açıkladı mı?" sorusuna hastaların çoğu $(2,58)$ olumlu cevap vermiştir. Soru 16'da "Hekim bazı test sonuçlarını size verdi mi?" sorusuna hastaların çoğu $(2,59)$ olumlu cevap vermiştir. Soru 10 ' da "Hekim size psikolojik destek sağladı mı?" sorusuna hastaların çoğu $(1,47)$ olumsuz cevap vermiştir. Soru 11'de "Hekim size psikolojik sorunlarınız ile ilgili açıklama yaptı mı?" sorusuna hastaların çoğu $(1,44)$ olumsuz cevap vermiştir.

Açılama (X:1,89-2,40), Psikolojik Destek (X:1,44-1,66) ve Tetkik (X:2,58-2,93) boyutlarının ortalamaları; 4 üzerinden 2 oranı ile değerlendirilmiştir. Ortalamalara göre, açıklama ve tetkik boyutlarının ortalamaları 2 değerinin üstünde, psikolojik destek boyutunun ortalaması ise 2 değerinin altında bulunmuştur ve bu sonuçlara göre hekimlerin, hastalarına yeterince açıklama ve tetkik yaptığı fakat psikolojik destek sağlayamadığı tespit edilmiştir. 
Tablo 1. Hastaların Hasta Hekim İletişimine İlişkin Bulguları

\begin{tabular}{|l|l|c|l|}
\hline No & Hasta Hekim İletişimi İle İlgili İfadeler & x & \multicolumn{1}{c|}{ s } \\
\hline s1 & Hekim hastalığınızın belirtilerini size söyledi mi? & 2,127 & 0,933 \\
\hline s2 & Hekim muayene sırasında hastalığınızın nedenini size anlattı mı? & 2,164 & 0,944 \\
\hline s3 & Hekim hastalığınızın gidişatını size açıkladı mı? & 2,189 & 0,915 \\
\hline s4 & Hekim hastalığınızın ciddiyetini size açıkladı mı? & 2,157 & 0,939 \\
\hline s5 & Hekim aldığınız tedavi ile ilgili size açıklama yaptı mı? & 2,401 & 0,933 \\
\hline s6 & $\begin{array}{l}\text { Hekim hastalığını ile ilgili duygusal anlamda hissettiklerinizin } \\
\text { nedenini size açılladı mı }\end{array}$ & 1,892 & 0,914 \\
\hline s7 & Hekim tıbbi tedaviniz ile ilgili size tavsiyelerde bulundu mu? & 2,279 & 0,920 \\
\hline s8 & Hekim hastalığınız ile ilgili sizin düşündüklerinizi anladı mı? & 2,451 & 0,826 \\
\hline s9 & Hekim hastalığınızla ilgili hissettiklerinizi anladı mı? & 2,339 & 0,848 \\
\hline s10 & Hekim size psikolojik destek sağladı mı? & 1,471 & 0,799 \\
\hline s11 & Hekim size psikolojik sorunlarınız ile ilgili açıklama yaptı mı? & 1,446 & 0,782 \\
\hline s12 & Hekim gergin olduğunuz durumlarda size yardımcı oldu mu? & 1,655 & 0,878 \\
\hline s13 & Hekim kendinizi kötü hissettiğinizde size yardımcı oldu mu? & 1,660 & 0,899 \\
\hline s14 & Hekim hastalığınızın nedenini bulmak için testler yaptı mı? & 2,937 & 0,876 \\
\hline s15 & Hekim bazı test sonuçlarını size açıkladı mı? & 2,586 & 1,112 \\
\hline s16 & Hekim bazı test sonuçlarını size verdi mi? & 2,596 & 1,116 \\
\hline
\end{tabular}

\section{Hasta Hekim İletişimine İlişkin Boyutların Psikometrik Özellikleri}

Hasta hekim iletişim anketine ait boyutların psikometrik özellikleri Tablo 2'de gösterilmektedir. 
Tablo 2.Hasta Hekim İletişimine İlişkin Boyutların Psikometrik Özellikleri

\begin{tabular}{|l|l|c|c|c|}
\hline No & Hasta Hekim İletişim Boyutları & İfade Sayısı & Max-Min & Cronbach Alfa \\
\hline 1 & Açıklama & 9 & $1-4$ & 0,883 \\
\hline 2 & Psikolojik Destek & 4 & $1-4$ & 0,849 \\
\hline 3 & Tetkik & 3 & $1-4$ & 0,800 \\
\hline 4 & Hasta hekim iletişim anketi & 16 & $1-4$ & 0,870 \\
\hline
\end{tabular}

Tablo 2'de görüldügüu üzere; açıklama boyutunun güvenilirlik alpha değeri $0,88^{\prime}$ dir. Psikolojik Destek boyutun güvenilirlik alpha değeri $0,84^{\prime}$ tür. Tetkik boyutun güvenilirlik alpha değeri ise 0,80 'dir. 16 maddenin güvenirlik değerinin 0.87 bulunması ile hasta hekim iletişim anketinin $\% 87$ ile oldukça yüksek güvenirliliğe sahip olduğu görülmüş̧ür. Elde edilen sonuçlara göre, boyutların alfa değerlerinin yüksek çıması güvenirlik ve geçerlilik açısından ölçeğin kullanıma hazır olduğunu göstermektedir.

\section{Korelasyon Tablosu}

Hasta hekim iletişiminin hekim tercihi ile ilişkisini gösteren korelasyon tablosu Tablo 3'te gösterilmektedir

Tablo 3. Korelasyon Tablosu

\begin{tabular}{|c|c|c|c|c|c|}
\hline \multicolumn{2}{|c|}{ Korelasyonlar } & $\begin{array}{c}\text { Aynı Hekimi } \\
\text { Tekrar Tercih } \\
\text { Etme }\end{array}$ & $\begin{array}{c}\text { Hekimi } \\
\text { Başkasına } \\
\text { Tavsiye Etme }\end{array}$ & $\begin{array}{c}\text { Verilen } \\
\text { Ilaçları } \\
\text { Kullanma }\end{array}$ & $\begin{array}{c}\text { Başka Hekime } \\
\text { Muayene } \\
\text { Olma }\end{array}$ \\
\hline \multirow{2}{*}{ Hekimin Iletişimi } & $\begin{array}{c}\text { Pearson } \\
\text { Correlation }\end{array}$ & $0,630^{* *}$ & $0,483^{* *}$ & $0,535^{* *}$ & $-0,252^{* *}$ \\
\cline { 2 - 6 } & $\mathbf{p}$ & 0,000 & 0,000 & 0,000 & 0,000 \\
\hline
\end{tabular}

Bu çalışmasının temel sorunsalı olan hasta hekim iletişiminin hekim tercihi ile ilişkisi araştırılmış olup Tablo 3'te görüldüğü üzere hekim iletişimi ile aynı hekimi tekrar tercih etme arasında pozitif ve anlamlı bir ilişki olduğu sonucuna varılmıştır. Başka bir ifadeyle, hekimin iletişimini iyi bulanlar aynı hekimi tekrar tercih edeceğini ifade etmiş ve bu değişkenler arasındaki ilişki istatistikî açıdan anlamlı bulunmuştur. Aynı şekilde hekimin iletişimi ile hekimin başkasına tavsiye edilmesi ve hekimin verdiği ilaçların kullanılması arasında da pozitif yönlü ve anlamlı bir ilişki vardır. Başka bir ifadeyle, hekimin iletişiminden memnun olan hasta; hekimini başkasına tavsiye etmekte ve hekimin verdiği ilaçları kullanmaktadır. Aynı tabloda hekim iletişimi ile başka hekime muayene olma isteği arasında negatif ve anlamlı bir ilişki bulunmaktadır. Bu sonuca göre ise hekim iletişiminden memnuniyet artıkça başka hekime 
muayene olma isteği azalmakta, hastalar ayn hekime muayene olmaya devam etmek istemektedir.

Sağlık kurumlarında hizmet kalitesini değerlendirmede kullanılan temel kriterlerden bir tanesi de hasta tatminidir (Uzkesici, 2002: 303). Yağbasan ve Çakar (2005:625) yaptığı çalışmada hekim ile kurulan iletişimden hoşnut olmanın aynı hekimin tekrar tercih edilmesinde etkili olup olmadığı ile ilgili bulgulara bakıldığında kısmen ve evet cevapları ile hastaların \%86'sı etkili olduğunu belirtmektedir. Taşlıyan ve arkadaşlarının (2012: 89) yaptığı bir araştırmada, devlet hastanelerini seçme nedeni olarak hastaların mecbur kalmaları, özel hastaneleri seçmelerinin en önemli nedeni olarak da hastaların önceki aldıkları hizmetten duydukları memnuniyet olduğu görülmektedir. Özel hastanelere giden hastaların $3 /{ }^{\prime}$ ü ise aynı hastaneyi başkalarına tavsiye edebileceğini belirtmişlerdir. Araştırmalara göre, iletişimin hasta memnuniyetini etkilediği ve seçme hakkı sunulduğunda hastaların daha önce aldıkları sağlık hizmetinden memnun oldukları kişileri tekrar seçme eğilimi gösterdikleri, gerektiğinde ise memnun kaldıkları hizmeti başkalarına tavsiye edebilecekleri görülmektedir. Bu araştırmanın sonuçlarına bakıldığında, literatüre benzer olarak; hastaların \%92,5'i hekimlerinin iletişimlerini iyi olarak değerlendirdiği, bu \%92,5 oranında hekimin iletişimini iyi olarak değerlendiren hastaların \%95'inin ise aynı hekimi tekrar tercih edeceği görülmektedir. Ayrıca hastaların \%90,8'inin aynı hekimi tekrar tercih ederim cevabını verdiği, \%30,7'sinin muayene olduğu hekime daha önce bir ya da birden fazla geldiği \%54,1'inin başka hekime muayene olmak istemediği ve ayn hekime devam edeceği görülmektedir. Sonuçlara göre bu çalışmada hekimin iletişiminden memnun olan hastaların; aynı hekimi tekrar tercih edeceği ve hekimi başkasına tavsiye edeceği tespit edilmiştir. Diğer çalışmalara bakıldığında bu araştırma sonuçlarına benzer oranlar görülmektedir. Özcan ve arkadaşlarının (2008: 99) yaptığı bir araştırmada bir ilçe hastanesine başvuran hastaların \% 76 'sı hastaneden memnun kaldığını ve \%75'i tekrar hastalanma durumunda aynı hastaneyi tercih edeceklerini, \%76'sı başkalarına da tavsiye edebileceklerini belirtmişlerdir. Aynı araştırmada hastaların \%90'ının hekimlerin davranışlarından, \%82'sinin kendilerine ayrılan muayene sürelerinden, \%78'inin bilgilendirmelerden memnun kaldığını belirtmektedir. Buna benzer olarak Bolu Düzce'de Aytar ve Yeşildal'ın (2004: 13) yaptığı bir çalışmada hastaların \%93'ü hastaneden memnun kalmakta ve \%94'ü ayn hastaneyi tekrar tercih edeceğini bildirmektedir. Yapılan başka bir çalışmada hastaların \%62,5'i muayene olduğu hekime tekrar gelebileceğini ve \%52'si hekimi başkalarına tavsiye edebileceğini belirtmiştir (Ersoy, 2005). Erdugan ve arkadaşlarının (2017: 176) yaptığı çalışmada elde edilen bulgulara göre hastaların \%87'si muayene oldukları hekimlerden memnun kaldıklarını, \%78,4'ü aynı hekimi tekrar tercih edeceğini, \%73'ü aynı hekimi tekrar tercih etmenin sebebi olarak; daha önce aldığı hizmetten memnun olma ve başkalarının tavsiyesi olarak belirtmektedir. Benzer bir araştırmanın sonucuna göre hekimlerin iletişimsel tutumlarından memnun olmanın, hastaların aynı hekimi tekrar tercih etmesinde etkili olduğu hipotezi doğrulanmıştır (Yağbasan ve Çakar, 2005: 627). Yapılan bu araştırmadan ve benzer diğer araştırmalardan anlaşılacağı gibi hastalar aldıkları sağlık hizmetlerinden memnun kaldıkları sürece aynı sağlık hizmetini tekrar tercih etmektedir. Yapılan bu araştırmada, hasta hekim iletişimi ile hekim tercihinin arasında pozitif bir ilişki olduğu hipotezi doğrulanmıştır. Hasta memnuniyetini etkileyen en önemli etkenlerden bir tanesi de hekim ile hasta arasındaki iletişimdir. Hastaların aynı hekimi tekrar tercih etmesinde etkili olan faktörler incelendiğinde birinci sırada hekim hasta arasında oluşan etkili iletişim yer almaktadır (Prudil ve Kanova, 2003: 45). Yapılan araştırmalarda, hasta ile hekim arasında doğru kurulan iletişim ile hasta memnuniyetinin ve uygulanan tıbbi uygulamalardan olumlu sonuç alma olasılığının arttığı tespit edilmiştir (Aksakal, 2003: 66). Şahin ve arkadaşlarının (2005: 140) yaptıkları bir araştırmada hastaların, birebir iletişim içinde oldukları kişiler ile onların sağladığı hizmetlerden memnun kaldıkları ve bu memnuniyetin hekimden, tıbbi bakım hizmetlerinden, hastaya gösterilen yakın ilgiden kaynaklandığı vurgulanmıştır. Önsüz ve arkadaşlarının (2008: 
47) yürüttüğü çalışmada hastaların yarısından fazlası $(\% 69,7)$ hastanede en memnun kaldıkları konunun, sağlık personelinin ilgisi ve güler yüzlü yaklaşım olduğunu belirtmişlerdir. Sağlık hizmeti sunumundan memnun kalan hastaların ihtiyaç duyduğunda tekrar aynı kuruma başvuracağı kabul edilmektedir (Ercan vd., 2004:151, Ercan vd., 2006: 73, Argan ve Argan, 2004: 46, Ay vd., 2004: 58, Konca vd., 2006: 160). Hastaların sağlık hizmeti aldığı kurum ve kişileri tekrar tercih etme oranlarına bakıldığında Önsüz ve arkadaşlarının (2008: 47) çalışmasında \%76, Aytar ve Yeşildal'ın (2004: 14) yaptığı bir çalışmada \%94 ve Konca ve arkadaşlarının çalışmasında (2006: 160) \%99, bu çalışmada ise \%90,8 olduğu görülmüştür. Hastaların sağlık hizmeti aldığı kurum ve kişileri bir başkasına tavsiye etme durumunu; Önsüz ve arkadaşları (2008: 47) \%70,7 oranı ile Tükel ve arkadaşları (2004: 206) \%88,6 oranı ile bu araştırma ise \%70,9 oranı ile tespit etmiştir.

\section{SONUÇ VE ÖNERİLER}

$\mathrm{Bu}$ çalışmanın temel sorunsalı olan hasta hekim iletişimi ile hekimin tekrar tercihinin değerlendirilmesi araştırılmış olup sonuçlar; hekim iletişimi ile hekimin tekrar tercih edilmesi arasında pozitif yönlü ve anlamlı bir ilişki olduğunu göstermiştir. Başka bir ifadeyle hekimin iletişimini iyi bulanlar aynı hekimi tekrar tercih edeceğini ifade etmiştir. Ayrıca sonuçlara göre hekimin iletişimini iyi bulanlar aynı zamanda hekimi başkalarına tavsiye etmekte, verdiği ilaçları kullanmakta ve başka hekime gitme ihtiyacı duymamaktadır. Bu değişkenler arasındaki ilişkiler istatistikî açıdan da anlamlı bulunmuştur. Hekimin tekrar tercih edilmesi ile hekimin açılayıcı olmasının ve tetkikler yapmasının arasında da olumlu ve pozitif bir ilişki bulunmuştur. Psikolojik destek boyutu değişkeni ile aynı hekimi tekrar tercih etme arasında anlamlı bir ilişki bulunmamıştır. Bunun nedeni olarak; çalışmaya katılan hastaların, hekimlerinin verdiği psikolojik desteği yetersiz görmesi olduğu düşünülmektedir.

$\mathrm{Bu}$ araştırmadan elde edilen bulgular 1şığında olumlu bir hasta hekim iletişimi için aşağıdaki öneriler sunulmuştur.

-Hekim hastaya zaman ayırıp, hastanın soru sormasına fırsat verebilir ve hastalığın belirtilerini, sebeplerini, gidişatını, ciddiyetini hastaya açıklayabilir.

-Hekimler, tıbbi terim kullanmadan açıklayıcı tarzda hastaları bilgilendirebilir ve hasta ile hekimin görüşme süreleri yeterli olacak şekilde ayarlanabilir.

-Hekimler hastalara psikolojik destek verme konusunda kendilerini geliştirebilir ve böylece yeterli donanıma sahip olabilirler.

-Her hasta ile kurulan iletişimin türü farklı olabilir. İletişim türü belirlenirken hastanın yararı göz önünde bulundurulmalıdır. Bunun sağlanması için tıp eğitiminde iletişim becerilerine önem verilebilir, tıp fakültesi öğrencilerinin hasta başında hasta ile diyalog kurması sağlanabilir.

-Hekim ve hasta arasında daha etkili bir iletişim sağlanabilmesi ve hekimlerin iletişim becerilerinin yeterli hale gelebilmesi için tıp fakültelerindeki ders programlarına hasta hekim iletişimi ile ilgili dersler konulabilir ve bu konuda eğitimler verilebilir.

-Hastane yönetimi tarafından iletişim politikaları belirlenebilir, programlar oluşturulabilir ve hekimlere başta iletişim olmak üzere halkla ilişkiler ve diyalog konularında eğitimler verilebilir. Bu eğitimlerin devamlılı̆̆ı sağlanabilir ve yönetim, hastaların memnun kaldığı hekimleri motive etmek için ödüllendirebilir .

-Hastanın aynı hekimi tekrar tercih etmesi için hekim seçme uygulaması sürdürebilir olabilir ve hastayı beğendiği, memnun kaldığı ve istediği hekim ile buluşturmak için düzenlemeler yapilabilir. 
Araştırmadan elde edilen sonuçlar yalnızca Isparta il merkezinde bulunan bir kamu hastanesinde 4 polikliniğe muayene olmaya gelen 401 hastanın görüşlerini yansıtmaktadır. Bu konuda genelleme yapabilmek için benzer araştırmaların daha geniş hasta örneklemi üzerinde çalışma yapması gerekebilir. Bundan sonra yapılacak çalışmalarda hasta hekim iletişimini derinlemesine araştırmak için vaka çalışması yapılabilir. Yapılan bu çalışmada hastaların görüşleri baz alınarak hekimin hasta ile olan iletişimi değerlendirilmiştir. Bir sonraki çalışmada hekimlerin görüşlerine de başvurulup hasta hekim iletişiminde hasta faktörünün etkisi araştırılabilir, elde edilen sonuçlar benzer araştırmaların sonuçları ile bütüncül bir şekilde değerlendirilip, ortaya çıkan öneriler sağlık hizmetlerini geliştirmek için kullanılabilir. Ayrıca oluşturulan bu yeni ölçeğin uygulanabilirliğini kanıtlamak için farklı zamanlarda yeni bir örneklem grubuna benzer ölçekler ile desteklenerek uygulanması önerilmektedir.

\section{KAYNAKÇA}

Akkoç, N. ve Güldal D. (2001). Kliniğe Giriş: Kavram ve Uygulamalar, DEÜ Tıp Fak Dergisi, 1(1): 75-8.

Aksakal, O. S. (2003). Türkiye'de Doktor Yetiştirme Programları-1: Biz neredeyiz?,Tıp Etiği Hukuku Tarihi Dergisi, 11(1): 64-8.

Argan, M. ve Argan, T.M. (2004, Temmuz- Eylül). Bursa İlindeki Özel Hastanelerde Poliklinik Hizmeti Alan Hastaların Kalite Algılamaları ve Memnuniyet Üzerine bir Araştırma, Modern Hastane Yönetimi Dergisi, Temmuz- Eylül:46-57.

Atıcl, E. (2007). Hasta-Hekim İlişkisini Etkileyen Unsurlar, Uludă̆ Üniversitesi Tıp Fakültesi Dergisi, 33(2): 91-96.

Ay, S. ve Güngör, N. ve Özbasaran, F. (2004). Manisa İl Merkezinde Birinci Basamak Sağlık Hizmetlerinden Yararlananların Aldıkları Hizmetten Memnuniyeti Üzerine Bir Araştırma, Modern Hastane Yönetimi Dergisi, Temmuz- Eylül: 58-62.

Aytar, G. ve Yeşildal, N. (2004). Yatan Hasta Memnuniyeti, Düzce Tıp Fakültesi Dergisi, 3: 10-4.

Bulduklu, Y. ve Koçak A. (2010). Sağlık İletişimi: Yaşlıların Televizyonda Yayınlanan Sağlık Programlarını İzleme Motivasyonları, Selçuk Üniversitesi İletişim Fakültesi Akademik Dergisi, 6(3): 5-17.

Chin, J.J. (2001). Doctor-Patient Relationship: A Covenant of Trust, Singapore Medical Journal, 42(12): 579-81.

Cirhinlioğlu, Z. (2001a). Sivas'ta Hekim-Hasta İlişkileri-II, C.Ü. Sosyal Bilimler Dergisi, 25(1): 4979.

Cirhinlioğlu, Z. (2001b). Sağglk Sosyolojisi.Ankara: Nobel Yayınları.

Çınarlı, İ. (2008). Sağlık İletişimi ve Medya.Ankara: Nobel Yayınları.

Ercan, İ. ve Ediz, B. ve Kan, İ. (2004). Sağlık Kurumlarında Teknik Olmayan Boyut için Hizmet Memnuniyetini Ölçebilmek Amacıyla Geliştirilen Ölçek, Uludağ Üniversitesi Tıp Fakültesi Dergisi, 30(3): 151-157.

Erdugan, F. ve Yörükbulut, S. ve Şahin, E. ve Öncel, S.Y. (2017, Mart). Kırıkkale Üniversitesi Tıp Fakültesi Hastanesinde Hasta ve Çalışan Memnuniyeti, Mehmet Akif Ersoy Üniversitesi Sosyal Bilimler Enstitüsü Dergisi, 9(18): 165-177. 
Ersoy, K. ve Malhan, S. (2009, Aralık). Hemşirelikte İletişime Yönelik Bir Araştırma. Joharı Penceresi, www.sabem.saglik.gov.tr/Akademik_Metinler/goto. aspx? id=2332.

Gordon, T. and Edwars, W. S., (1997). Making the Patient Your: Communication Skills for Doctor and Other Caregivers, Santa Barbara: ABCCLIO, LLC.

Hardoff, D. and Schonmann, S. (2001). Training Physicians in Communication Skills with Adolescents using Teenage Actors as Simulated Patients, Med Educ, 35(3): 206-210.

Karasar, N. (2014). Bilimsel Araştırma Yöntemi.Ankara: Nobel Yayınları.

Kavuncubaşı, Ş. (2000). Hastane ve Sağlık Kurumları Yönetimi. Ankara: Siyasal Kitapevi.

Konca, G. ve İlhan, N.M. ve Bunin, M.A. (2006). Yatarak Tedavi Gören Hastaların Hastane Çalışanları ve Hastane Hizmetlerinden Beklentileri ve Beklentilerine İlişkin Memnuniyet Durumlarının Değerlendirilmesi, Gazi Tip Dergisi, 17(3): 160-170.

Kostik, Z. (1999). Olağanüstü Hal Bölgesinde Yaralanarak GATA Ĕ̆itim Hastanesinde Tedavi Gören Hastalarm Doktor-Hasta İlişkisi ve Bu İlişkiden Kaynaklanan Tatmin Düzeylerinin Araştırılması, Yüksek Lisans Tezi, 72. Genel Kurmay Başkanlığı Gülhane Askeri Tıp Akademisi, Ankara.

Kurtz, S. and Silverman, J. and Draper, J. (1998). Tıpta İletişim Teknikleri, (Çeviren, Selim, Y., Ayşegül, Y., Murat, Y.) İstanbul: Beyaz Yayınları.

Okay, A. (2009). Kurum İçi İletişimin Hizmet Kalitesine Etkileri, SAYED (Sağlık Yönetimi ve Ĕ̆itimi Dergisi), 2(19): 18-21.

Önsüz, F.M. ve Topuzoğlu, A. ve Cöbek, U.C. ve Ertürk, S. ve Yılmaz, F. ve Birol, S. (2008). İstanbul'da Bir Tip Fakültesi Hastanesinde Yatan Hastaların Memnuniyet Düzeyi, Marmara Medikal Journal, 21(2): 33-49.

Özcan, M. ve Özkaynak, V. ve Toktaş, İ. (2008). Silvan Devlet Hastanesine Başvuran Kişilerin Memnuniyet Düzeyleri, Dicle Tıp Dergisi, 35(2): 96-101.

Özlü, T. (2003). Hekiminizi Nasıl Alırdınız? İstanbul: Kaknüs Yayınları.

Prudil, L. and Kanova, P. (2003). Communication: An İmportant Factor in Patient Decision Making, Eurohealth-London, 8(5): 43-45.

Rimal, R. N. and Adkins, A. D. (2003). Using Computers to Narrowcast Health Messages: The Role of Audience Segmentation, Targeting and Tailoring in Health Promotion (Ed.)Thompson, T.L. and Dorsey, A.M. andMileer, K.I. and Parrott, R., Handbook of Health Communication (ss.497513), Lawrence Erlbaum Associates, Publishers, Mahwah, New Jersey: London.

Sabuncuoğlu, Z. ve Tüz, M. (1998). Örgütsel Psikoloji. (3. Baskı), Bursa: Alfa Yayınları.

Sezgin, D. (2008). Haber Medyası Savunuculuk: Planlama ve Stratejiler, İletişim Araştırmaları, 6(2): 145-163.

Street, J.R. and Richard L. (2003). Communication in Medicalencounters: An Ecological Perspective, (Ed.)Thompson, T.L. and Dorsey, A.M. and Mileer, K.I. and Parrott, R., Handbook of Health Communication(ss.63-89), Lawrence Erlbaum Associates, Publishers, Mahwah, New Jersey: London.

Şahin, D. (1999). Hasta-Tedavi İlişkisi, (Editör) Ülgen, H.O., Sağlık Psikolojisi içinde (s.39-78) Konya: Türk Psikologlar Derneği Yayınları. 
Şahin T.K. ve Bakıcı H. ve Bilban S. ve Dinçer Ş. ve Yurtçu M. ve Günel E. (2005).Meram Tıp Fakültesi Çocuk Cerrahisi Servisinde Yatan Hasta Yakınlarının Memnuniyetinin Araştırılması,Genel Tip Dergisi,15:137-142.

Tabak, R. S. (2006). Sağlık İletişimi. (3. Baskı), İstanbul: Literatür Yayıncılık.

Taşliyan, M. ve Gök, S. (2012). Kamu ve Özel Hastanelerde Hasta Memnuniyeti: Kahramanmaraş'ta Bir Alan Çalışması, Kahramanmaraş Üniversitesi (KSÜ) Sosyal ve Akademik Araştırmalar Dergisi,2(1): 69-94.

Tükel, B. ve Acuner, M. A. ve Önder, R.Ö. ve Üzgül, A. (2004). Ankara Üniversitesi İbni Sina Hastanesi'nde Yatan Hasta Memnuniyeti (Genel Cerrahi Anabilim Dalı Örneği), Ankara Üniversitesi Tip Fakültesi Mecmuası,57(4): 205-24.

Uyer, G. (2000). Hemşire ve Hasta İletişiminin Hasta Yönünden Önemi,Türkiye Klinikler Dergisi, 8: $90-94$.

Uzkesici, N. (2002). Sağllk Kurumları Yönetimi. Eskişehir: Anadolu Üniversitesi Açık Öğretim Yayınları.

Van Den B. M. A. and Verhaak, P. F. M. and Bensing, J. M. and Bahrs, O. and Deveugele, M. and Gask, L. and Peltenburg, M. (2000). Doctor-Patient Communication in Different European Health Care Systems: Relevance and Performance from the Patients' Perspective. Patient Education And Counseling, 39 (1), 115-127.

Valori, R. and Woloshynowych, M. and Bellenger, N. and Aluviklhare, V. and Salmon, P. (1996). The Patient Requests Form: A Way of Measuring What Patients Want from Their General Practitioner. Journal of Psychosomatic Research, 40 (1), 87-94.

Yağbasan, M. ve Çakar, F. (2005). Doktor-Hasta İlişkisinde Dil ve Davranışa Dayalı İletişimsel Sorunları Belirlemeye Yönelik Bir Alan Araştırması, Selçuk Üniversitesi Sosyal Bilimler Enstitüsü Dergisi. 19: 609-630.

Zerenler, M. ve Öğüt, A. (2007). Sağlık Sektöründe Algilanan Hizmet Kalitesi ve Hastane Tercih Nedenleri Araştırması: Konya Örneği, Selçuk Üniversitesi Sosyal Bilimler Enstitüsü Dergisi, 18: 500519 . 